\title{
Role of metabotropic glutamate receptor 5 signaling and homer in oxygen glucose deprivation-mediated astrocyte apoptosis
}

Maryse Paquet ${ }^{1}$, Fabiola M Ribeiro ${ }^{2}$, Jennifer Guadagno ${ }^{1}$, Jessica L Esseltine ${ }^{1}$, Stephen SG Ferguson ${ }^{\text {* }}$ and Sean P Cregan ${ }^{1 *}$

\begin{abstract}
Background: Group I metabotropic glutamate receptors ( $\mathrm{mGluR}$ ) are coupled via $\mathrm{Ga}_{\mathrm{q} / 11}$ to the activation of phospholipase $C \beta$, which hydrolyzes membrane phospholipids to form inositol 1,4,5 trisphosphate and diacylglycerol. In addition to functioning as neurotransmitter receptors to modulate synaptic activity, pathological mGluR5 signaling has been implicated in a number of disease processes including Fragile $X$, amyotrophic lateral sclerosis, multiple sclerosis, Alzheimer's disease, Parkinson's disease, Huntington's disease, epilepsy, and drug addiction. The expression of mGluR5 in astrocytes has been shown to be increased in several acute and chronic neurodegenerative conditions, but little is known about the functional relevance of mGluR5 up-regulation in astrocytes following injury.
\end{abstract}

Results: In the current study, we investigated primary mouse cortical astrocyte cell death in response to oxygen glucose deprivation (OGD) and found that OGD induced both necrotic and apoptotic cell death of astrocytes. OGD resulted in an increase in astrocytic mGluR5 protein expression, inositol phosphate formation and extracellular regulated kinase (ERK1/2) phosphorylation, but only inositol phosphate formation was blocked with the mGluR5 selective antagonist MPEP. Cortical astrocytes derived from mGluR5 knockout mice exhibited resistance to OGDstimulated apoptosis, but a lack of mGluR5 expression did not confer protection against necrotic cell death. The antagonism of the inositol 1,4,5 trisphosphate receptor also reduced apoptotic cell death in wild-type astrocytes, but did not provide any additional protection to astrocytes derived from mGluR5 null mice. Moreover, the disruption of Homer protein interactions with mGluR5 also reduced astrocyte apoptosis.

Conclusion: Taken together these observations indicated that mGluR5 up-regulation contributed selectively to the apoptosis of astrocytes via the activation of phospholipase $\mathrm{C}$ and the release of calcium from intracellular stores as well as via the association with Homer proteins.

Keywords: Astrocyte, Metabotropic glutamate receptor, Cell death, Inositol phosphate, Oxygen glucose deprivation, Homer

\footnotetext{
* Correspondence: ferguson@robarts.ca; scregan@robarts.ca

1J. Allyn Taylor Centre for Cell Biology, Robarts Research Institute,

Department of Physiology and Pharmacology, The University of Western

Ontario, 100 Perth Drive, London, ON N6A 5K8, Canada

Full list of author information is available at the end of the article
} 


\section{Background}

Several neurotransmitter receptors are expressed in astrocytes including the $G$ protein-coupled receptors (GPCRs) for the excitatory neurotransmitter glutamate. The metabotropic glutamate receptors (mGluRs) comprise the family $\mathrm{C}$ of GPCRs, which are characterized by sequence similarities in their seven transmembrane spanning helical domains and large extracellular aminoterminal venus fly trap domain [1-3]. Eight distinct mGluRs have been identified and are divided into three subgroups based on sequence homology and $G$ protein coupling-specificity. Group I mGluRs (mGluR1 and mGluR5) are predominantly coupled to the activation of phospholipase C (PLC) via $G \alpha_{\mathrm{q} / 11}$, whereas Group II (mGluR2 and mGluR3) and Group III (mGluR4, mGluR6, mGluR7 and mGluR8) mGluRs negatively regulate adenylyl cyclase via $\mathrm{G}_{\mathrm{i}}$. Group I mGluR stimulation leads to $\mathrm{G} \alpha_{\mathrm{q} / 11}$-mediated intracellular activation of second messenger pathways, $\beta \gamma$ activation of ion channels, as well as stimulation of $G$ proteinindependent pathways [2-4]. Pharmacological and biochemical experiments have shown that mGluR5 is the predominant group I mGluR subtype expressed in cultures of brain astrocytes [5,6] although mGluR1 is also expressed in astrocytes in the spinal cord [7].

Astrocytic mGluR5 has been shown to play key roles in glia-neuron interactions, regulation of glutamate reuptake, and the coupling of the neurovasculature to neuronal activity [8-10]. However, the roles of mGluR5 in both astrocytic and neuronal survival following injury are poorly understood. In neurons, Group I mGluRs have been reported to both protect against and exacerbate cell death, depending on the model of toxicity employed, the neuronal subtype involved, and prior activation state of the receptors themselves [11-17]. The variety of signaling pathways activated by mGluR $1 / 5$ may explain these observations. Group I mGluRs coupled to $\mathrm{G \alpha}_{\mathrm{q} / 11}$ proteins stimulate the activation of PLC resulting in diacylglycerol and inositol-1,4,5-triphosphate (InsP3) formation. By interacting with InsP3 receptors, InsP3 induces calcium release from intracellular stores potentially leading to inappropriate cell death [18]. On the other hand, mGluR1/5 stimulation also leads to activation of other signaling pathways important for cell survival/proliferation, such as extracellular signal-regulated kinases 1/2 (ERK1/2) and AKT $[19,20]$. Consistent with these opposing effects on cell survival, the mGluR1/5 scaffold protein Homer has been shown to promote the activation of both pro- and anti-survival signaling pathways $[19,21]$.

Group I mGluR expression is up-regulated in models of epilepsy, brain injury, amyotrophic lateral sclerosis, and multiple sclerosis [22-25]. Alterations in glutamate signaling are also known to play a prominent role in ischemic brain injury and both apoptotic and necrotic astrocytes have been observed following in vivo ischemic insults [26-30]. However, very little is known about the functional consequences of elevated mGluR5 expression on astrocyte survival following injury. Therefore, in the present study, we utilized an in vitro model of ischemia/ reperfusion, oxygen glucose deprivation (OGD), to evaluate the potential role of alterations in mGluR5 protein expression following the injury of astrocytes. We find that OGD induces astrocytic cell death by both apoptotic and necrotic mechanisms and results in a rapid increase in mGluR5a expression that is independent of gene transcription. The observed OGD-induced apoptotic cell death is associated with increased mGluR5-dependent inositol phosphate formation and is reduced in astrocytes isolated from mGluR5 knockout mice. Moreover, OGD-induced apoptotic death of cortical astrocytes was reduced following IP3 receptor antagonism and Tat-Homer peptide-mediated interference of Homer interactions with mGluR5. Taken together, these observations indicate that upregulation of mGluR5 expression contributes to OGD-induced cell death via a $\mathrm{G \alpha}_{\mathrm{q} / 11}$ and Homer mediated mechanism.

\section{Results \\ OGD induces both necrotic and apoptotic cell death of cortical asrtocytes}

To assess the effects of OGD on cortical astrocyte cell death, primary CD1 mouse cortical astrocytic cultures were subjected to an in vitro model of OGD to mimic ischemia (no oxygen and no glucose) for periods varying from 0 to $24 \mathrm{~h}$ followed by a $24 \mathrm{~h}$ reperfusion period (normal oxygen and glucose conditions). Under these conditions, astrocytes survived OGD treatment for $6 \mathrm{~h}$ (Figure 1A). However, further incubation without glucose and oxygen (12-24 h) led to a decrease in metabolic activity (Figure 1A). Both necrotic cell death as measured by the release of $\mathrm{LDH}$ by the dying astrocytes (Figure 1B) and apoptotic cell death as indicated by chromatin condensation observed in Hoechst-stained nuclei (Figure 1C) was induced following a $24 \mathrm{~h}$ OGD exposure time (Figure 1D). Thus, the reduction in astrocytes viability in response to OGD was associated with a mix of necrotic and apoptotic astrocytic cell death.

\section{OGD-induced increase in mGluR5 protein expression} correlates with an increase in mGluR5-dependent inositol phosphate signaling

Cortical mouse astrocytes primarily express mGluR5a $[5,6]$ and Group I mGluR expression have been previously shown to be up-regulated in models of brain injury, epilepsy, amyotrophic lateral sclerosis, and multiple sclerosis [22-25]. Therefore, we examined whether mGluR5a protein expression was altered following OGD 


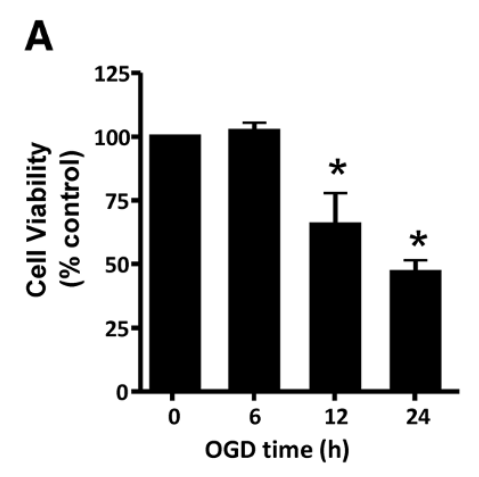

\section{C}

B

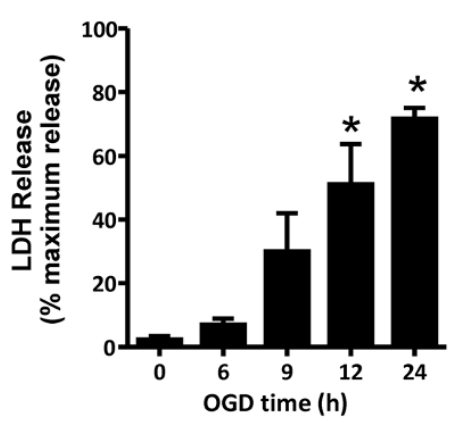

OGD

Oh

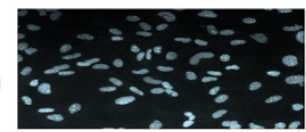

$12 \mathrm{~h}$

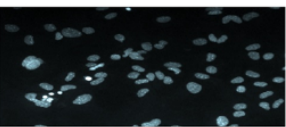

$24 \mathrm{~h}$

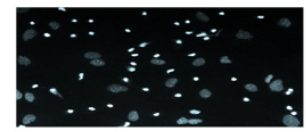

D

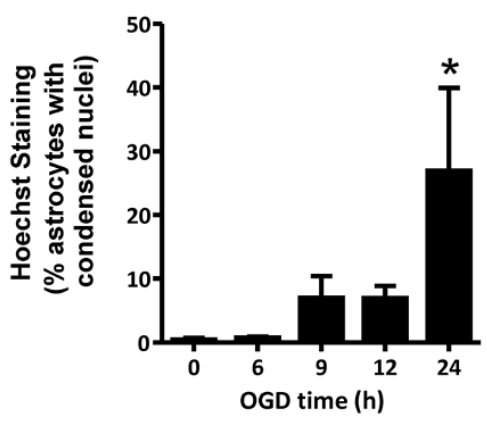

Figure 1 OGD induces both necrotic and apoptotic cell death in cultured cortical astrocytes. A) Cell viability of cultured cortical astrocytes, as assessed by the metabolic MTT assay following 0-24 h OGD followed by $24 \mathrm{~h}$ reperfusion. B) Necrotic cell death measured by lactate dehydrogenase (LDH) assay following 0-24 h OGD followed by $24 \mathrm{~h}$ reperfusion. C) Representative photomicrographs of primary CD1 cortical astrocytes cultures that were OGD treated for 0,12 , and 24 hours followed by $24 \mathrm{~h}$ reperfusion and stained with Hoescht dye to reveal cells dying by apoptosis as evidenced by condensed chromatin/ pyknotic nuclei. D) Quantification of apoptotic CD1 astrocytic cell death following 0$24 \mathrm{~h}$ OGD followed by $24 \mathrm{~h}$ reperfusion. All data represents the mean \pm SD of 5 independent experiments and were analyzed by ANOVA followed by Dunnet's post-hoc testing, ${ }^{*} p<0.05$ versus untreated control cultures.

treatment of primary cortical mouse astrocytes. As determined by immunoblotting for mGluR5a, the levels of mGluR5a expression in astrocytic cultures was not detectable by immunoblot in primary CD1 mouse cortical astrocytes, but OGD treatment (2-12 h) resulted in increased mGluR5a expression (Figure 2A and B). However, the increase in mGluR5a expression was not correlated with an increase in mGluR5a mRNA expression as determined by RT-PCR (Figure 2C) suggested that either mGluR5 turnover or mGluR5 protein translation was altered as a consequence of OGD.

\section{OGD-induced increase in mGluR5 protein expression} correlates with an increase in mGluR5-dependent inositol phosphate signaling

Because mGluR5a protein expression was increased by OGD, we assessed whether mGluR5-dependent inositol phosphate (InsP) formation and ERK1/2 phosphorylation was altered in response to OGD. As shown in Figure 3A, InsP formation in cortical astrocytes following $4 \mathrm{~h}$ OGD was significantly increased compared to non-ischemic cultures ( $0 \mathrm{~h}$ OGD). The observed increase in InsP formation in response to OGD was blocked by treating the astrocytic cultures with the mGluR5-specific inverse agonist MPEP (100 $\mu \mathrm{M})$ (Figure 3A). OGD treatment of cortical astrocyte cultures for increasing periods of time (3-24 h) resulted in a treatment and time-dependent increase in ERK1/2 phosphorylation (Figure 3B). However, unlike what was observed for InsP formation following OGD, MPEP treatment $(100 \mu \mathrm{M})$ of the astrocytic cultures did not inhibit OGD-induced increases in ERK1/2 phosphorylation (Figure 3C). These data suggested that the mGluR5 receptors induced by OGD contributes to increased InsP formation, but that increases in ERK1/2 activity induced by OGD likely occurred independently of mGluR5.

mGluR5 promotes apoptotic, but not necrotic astrocytic cell death

To investigate the selective contribution of mGluR5 to either necrotic and/or apoptotic cell death induced by OGD, we exposed cortical astrocytes derived from either wild-type (mGluR5+/+) or mGluR5 knock-out (mGluR5-/-) mice to OGD for 6-24 h. Apoptotic cell death induced by OGD treatment was reduced in 


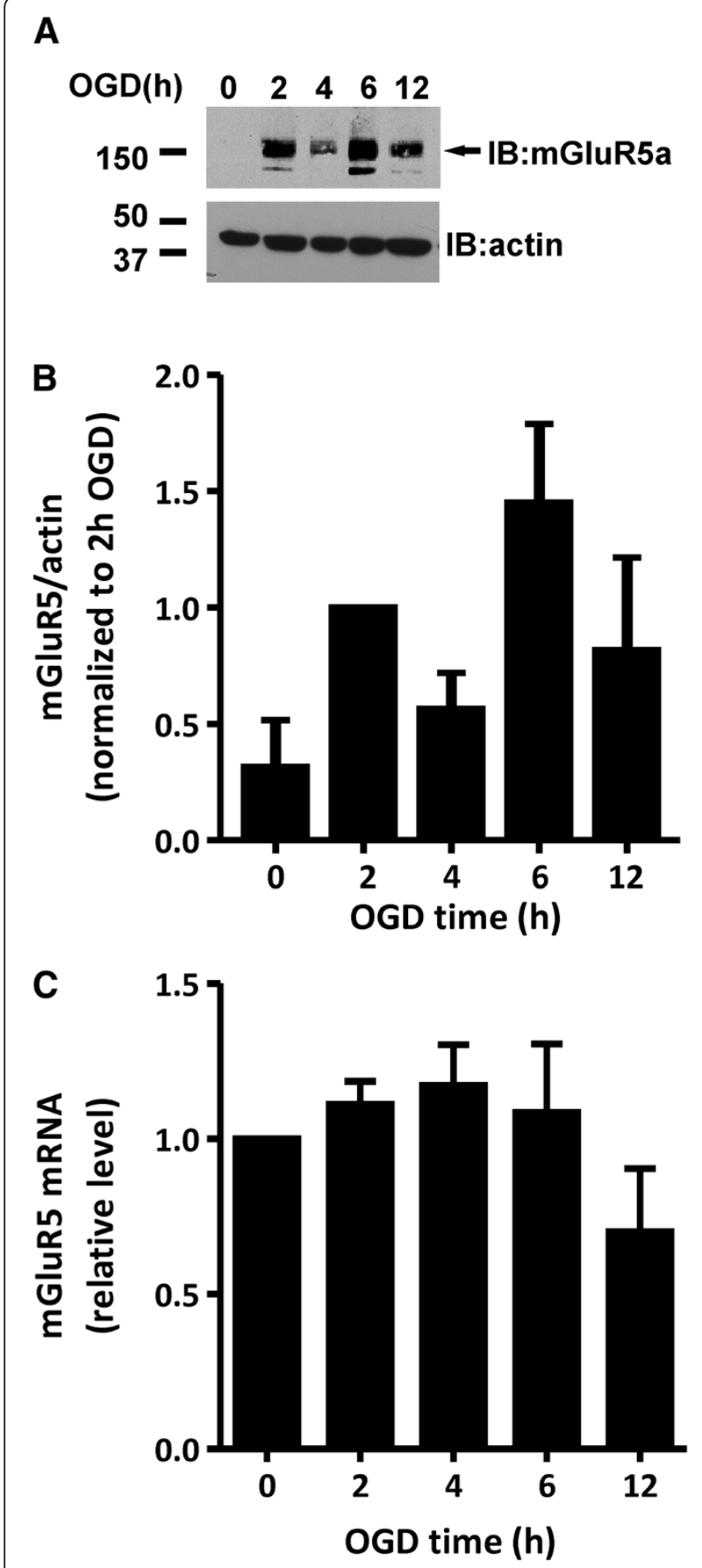

Figure 2 mGluR5a protein expression is increased in cortical astrocytic cultures in response to OGD. A) Representative immunoblot showing increases in mGluR5a protein expression at 0 , 2, 4, 6, and $12 \mathrm{~h}$ following OGD treatment. B) Quantification of mGluR5a protein expression in primary CD1 mouse cortical astrocytes following 0-12 h OGD. Data is normalized to mGluR5a protein expression at $2 \mathrm{~h}$. Data represents the mean \pm SD of 4 independent experiments. C) Real time RT-PCR analysis shows no significant change in mGluR5 mRNA levels in cortical astrocytes after OGD. mGluR5 mRNA levels were normalized to mitochondrial S12 transcript levels and data represents mean \pm SD from three independent experiments.

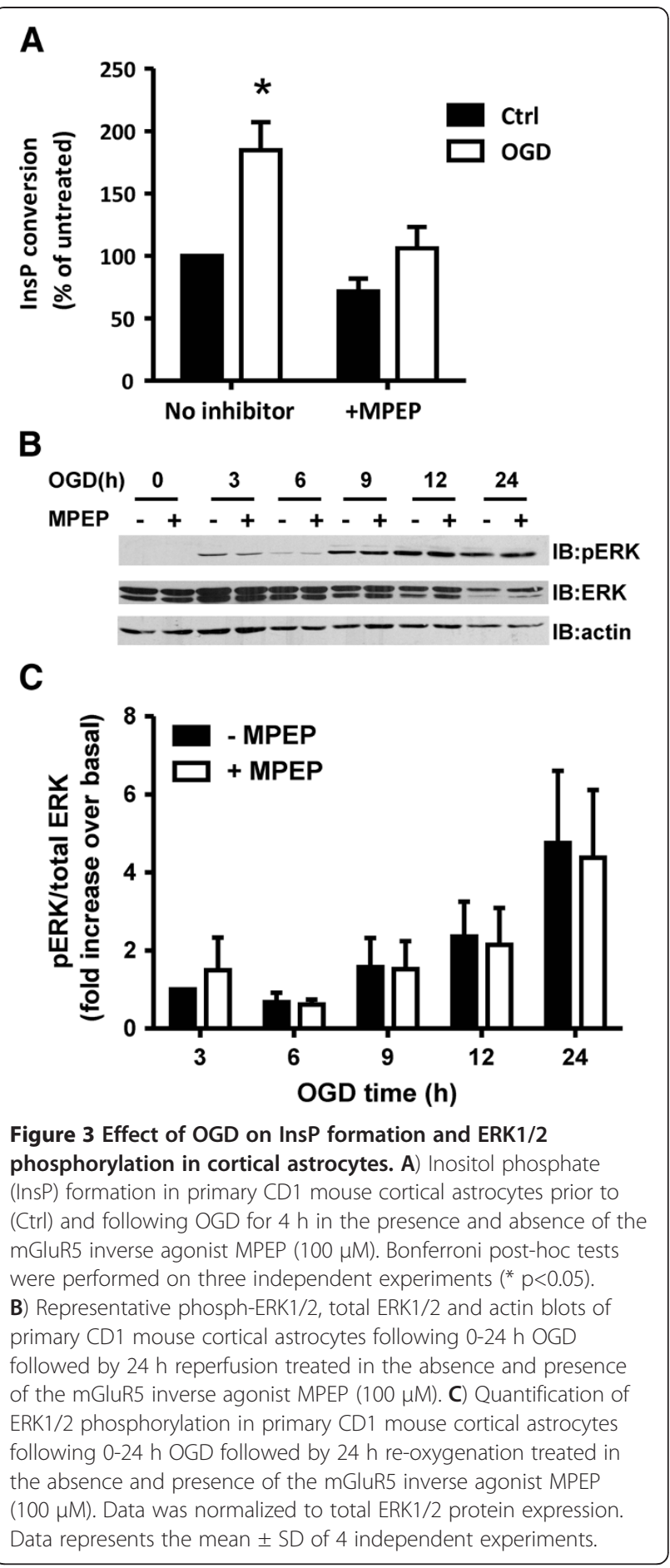

astrocytes that lacked mGluR5, as assessed by Hoechststained condensed nuclei (Figure 4A). A two way ANOVA analysis demonstrated that the two genotypes were responding differently to OGD treatment for 6$24 \mathrm{~h}$ followed by a $24 \mathrm{~h}$ reperfusion treatment (Figure 4B). Specifically, the mGluR5 null genetic background provided significant protection against OGDmediated apoptosis (Figure 4B). OGD treatment also 


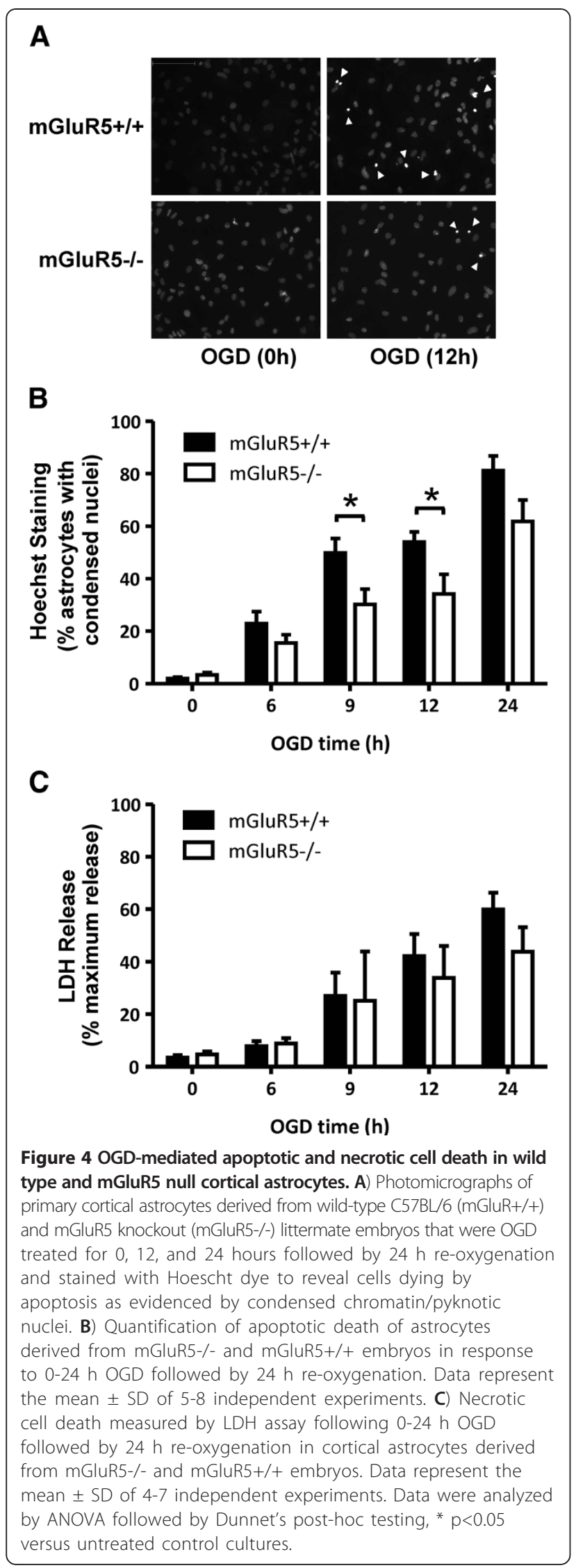

resulted in increased necrotic cell death with time, as measured by increased LDH release (Figure 4C). However, necrotic astrocytic cell death in response to OGD was not attenuated in cortical mouse cultures derived from mGluR5-/- mouse embryos (Figure 4C). Taken together, these observations suggested a role for mGluR5 signaling in apoptotic, but not necrotic, astrocyte cell death following OGD.

\section{OGD induced apoptosis requires mGluR5-dependent InsP3 receptor activation}

To further delineate whether the observed increase in InsP formation in response to OGD was dependent upon mGluR5 expression, we tested whether the antagonism of the IP3 receptor with the InsP3 receptorspecific inhibitor Xestospongin $C$ would alter OGD induced apoptosis of astrocytes derived from wild-type and mGluR5-/- embryos. We found that Xestospongin C treatment significantly reduced the apoptotic cell death of wild-type astrocytes following $12 \mathrm{~h}$ of OGD treatment, but did not affect OGD-induced apoptosis of astrocytes derived from mGluR5-/- mice (Figure 5A). Furthermore, as shown previously (Figure 4B), the OGD-induced apoptosis of mGluR5-/- astrocytes was significantly reduced when compared to wild-type cultures and was not significantly different from wild-type cultures treated with Xestospongin C (Figure 5A). In contrast, the OGD time-dependent increase in ERK1/2 phosphorylation was not attenuated in astrocytic cultures derived from mGluR5-/- mice (Figure 5B and C). Taken together, these results further support the pharmacological data indicating that mGluR5 contributed to OGD-induced apoptosis as the consequence of InsP3 receptor activation, but does not contribute to increases in ERK1/2 phosphorylation.

Role for Homer in OGD mediated astrocytic cell death It has been suggest that Homer proteins may regulate the efficiency of mGluR5-mediated activation of the InsP3 receptor [21], therefore we tested whether the treatment of astrocytes with a cell permeable Tat-tagged peptide corresponding to the mGluR5 Homer binding domain (Homer peptide) would attenuate OGD-induced astrocytic cell death [19]. Human embryonic kidney (HEK 293) cells were transfected with Flag-mGluR5a and Homer $1 \mathrm{~b}$ to confirm that the Homer peptide disrupted mGluR5a/ Homer $1 \mathrm{~b}$ interactions by co-immunoprecipitation. We found that treatment of transfected HEK 293 cells with Homer peptide $(35 \mu \mathrm{M})$, but not a scrambled peptide for $1 \mathrm{~h}$ antagonized the co-immunoprecipitation of Homer $1 \mathrm{~b}$ with Flag-mGLuR5a (Figure 6A). Subsequently, the treatment of primary mouse cortical astrocytes with Homer peptide resulted in the reduction of astrocytic apoptotic cell death, when compared to astrocytes treated with 


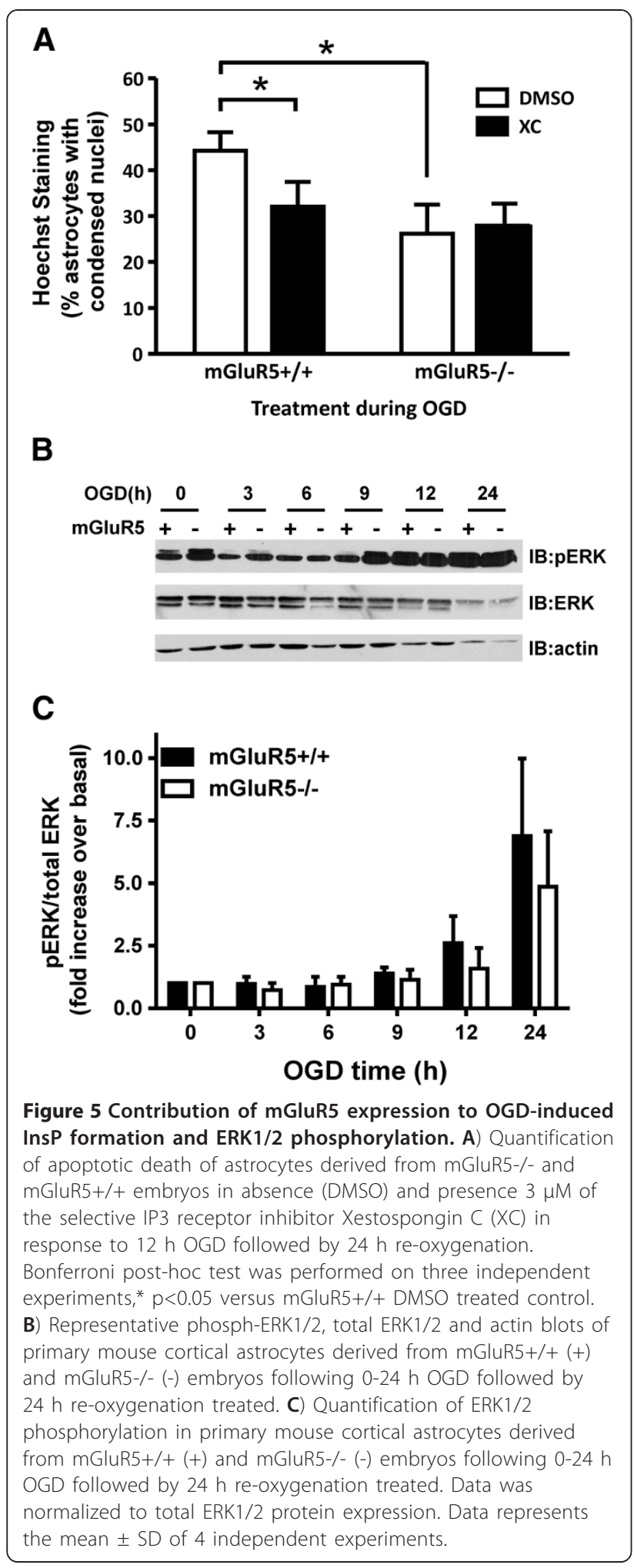

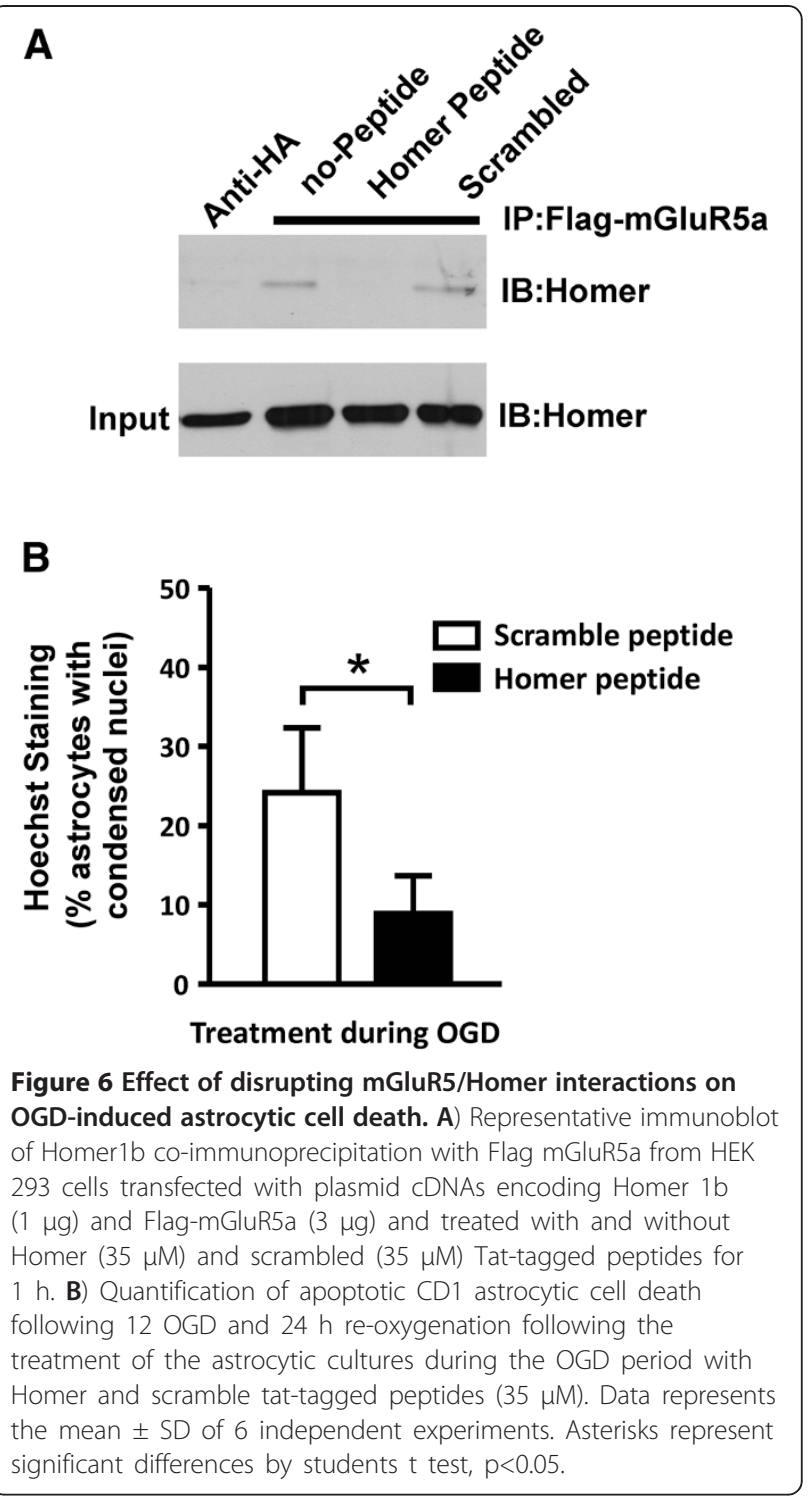

scrambled peptide (Figure 6B). Thus, mGluR5a/Homer interactions appeared to also contribute to mGluR5mediated apoptotic cell death following OGD treatment.

\section{Discussion}

In the present study, we show that OGD induces both apoptotic and necrotic astrocytic cell death. We find that similar to what is observed for both acute and chronic neurodegenerative conditions, such as pain, amyotrophic lateral sclerosis, multiple sclerosis, and epilepsy [22-25,31-33] OGD also results in an increase in mGluR5a expression. We find InsP formation in cortical astrocytes is increased following OGD and that the treatment of cultures with the mGluR selective antagonist MPEP, not only attenuates OGD-mediated InsP formation, but the genetic deletion of mGluR5 selectively protects against OGD-induced apoptosis. The effects of 
mGluR5 are independent of the activation of the ERK1/2 signaling pathway, but appear to be associated with increased signaling via the PLC-InsP3-calcium pathway and Homer protein interactions.

We show that the mGluR5a expressed in response to injury are functional and activated after the ischemic insult. Group I mGluRs are known for their high constitutive and agonist-independent activity when they are overexpressed in heterologous systems [34]. However, in this case, because OGD-induced mGluR5 expression in astrocytes is not as high as those found in neuronal cultures or in transfected cells [20], increased mGluR5 activity may also be due to glutamate released by astrocytes in response to ischemia. Indeed, ischemic conditions could result in glutamate release by astrocytes through a variety of mechanisms [35]. The observed increases in InsP formation following OGD are consistent with previous work demonstrating that OGD results in increased InsP formation, likely via a metabotropic glutamate receptor [36].

We observe that OGD treatment activates a timedependent increase in ERK1/2 phosphorylation that appears to be independent of mGluR5 activity, as increases in ERK1/2 phosphorylation were not antagonized by treatment of cultures with the mGluR5 selective antagonist MPEP. Furthermore, the genetic deletion of the mGluR5 gene did not result in diminished ERK1/ 2 phosphorylation in response to OGD. Indeed, in contrast to the InsP3 pathway, the mGluR5-induced activation of MAPK pathway occurs via mechanisms that are largely independent of PLC activation and calcium release in both striatal neurons (Homer protein dependent) and astrocytes (EGF receptor transactivation) $[19,37,38]$. The OGD-induced increase in ERK activation in astrocytes, as previously reported [39], did not significantly change in presence of the mGluR5 antagonist MPEP. Thus, it is possible that glutamate released in response to OGD may activate alternative mGluR subtypes that may be directly linked to the activation prosurvival signal transduction pathways in astrocytes. Consistent with this, mGluR3 is implicated in protecting against astrocytes apoptosis following OGD [40].

Interestingly, the mGluR5-dependent activation of PLC-mediated signaling leads to excessive calcium release and excitotoxic striatal neuronal death, which could be prevented by the down regulation of Group I mGluR expression following estradiol treatment [18]. Thus, a selective increase in PLC signaling likely correlates with a pro-apoptotic role for astrocytic mGluR5, as OGD-induced apoptosis is reduced in astrocytes derived from mGluR5 null embryos. Moreover, selective mGluR5 blockade has been reported to be neuroprotective [41]. Thus, it appears that increased mGluR5 signaling in astrocytes might lead to cell death following
OGD-increased mGluR5a protein expression levels. Interestingly, mGluR5 has been shown to be upregulated in the spinal cord of ALS patients [22,24] and astrocytic cell death in an amyotrophic lateral sclerosis transgenic model has been shown to be attenuated by blocking the mGluR5 receptor in vivo [42]. Moreover, the disease onset was also delayed by this treatment. Similarly, the brain permeable mGluR5 antagonist MTEP provides neuroprotection in an in vivo ischemic model [17].

Because the effect of the InsP3 receptor inhibitor Xestospongin $\mathrm{C}$ on apoptosis is not observed in astrocytes lacking the mGluR5, we have confirmed that the mGluR5PLC-InsP3-calcium signaling pathway is responsible for induction of apoptosis by releasing calcium from intracellular stores. As reviewed by Hanson et al. [43], calcium released through InsP3 receptors is sequestered by mitochondria and mitochondrial calcium overload can induce the apoptotic cascade. In addition, calcium release can also stimulate calcium-sensitive enzymes such as the phosphatase calcineurin, which is involved in other apoptotic mechanisms [43]. Furthermore, we show that the formation of a molecular complex between Homer proteins and mGluR5 contributes to the activation of a proapoptotic pathway, as the treatment of astrocytes with a Tat-Homer interference peptide reduced OGD-induced astrocytes apoptosis. This Tat-peptide was previously shown to block mGluR5/Homer interactions but also blocks Homer-dependent activation of ERK1/2 [19]. Thus, although we did not observe reduced ERK1/2 phosphorylation in response to OGD following either MPEP treatment or the loss of mGluR5 expression, it is possible that mGluR5-dependent activation of the ERK1/2 pathway via a Homer-dependent mechanism may also function to antagonize mGluR5-mediated apoptosis of astrocytes that is induced as the consequence of PLC-mediated mGluR5 signaling.

In conclusion, because of the neuroprotective role of astrocytes, astrocytic cell death could have a huge impact on acute or chronic neurodegenerative conditions. Thus, targeting mGluR5-signaling pathway involved in the induction of astrocyte apoptosis may have therapeutic benefits following ischemic insults such as stroke. For example, selective blockade of mGluR5-dependent PLC signaling in astrocytes might help limit cellular loss in a variety of neurodegenerative diseases. In contrast, the selective activation of mGluR5 $\mathrm{G}$ protein-mediated PLC signaling might promote apoptotic cell death in brain tumors, such as astrocytomas. This is of particular importance considering that mutations in mGluR1a have been associated with a variety of tumors, and that many of the mutations bias receptor signaling via the activation of ERK1/2 at the expense of $G$ protein signaling [44-46] suggesting it may be possible to design biased 
allosteric agonists to prevent both astrocytic and neuronal cell death.

\section{Methods \\ Materials}

2-Methyl-6-(phenylethynyl) pyridine hydrochloride (MPEP) was purchased from Tocris Cookson (Ellisville, MO). All cell culture reagents were from Invitrogen (Burlington, $\mathrm{ON}$ ). Cytotoxicity detection kit plus (lactose dehydrogenase, LDH) was from Roche (Mississauga, ON). Rabbit anti-mGluR5 antibodies were from Millipore (Billerica, MA). Rabbit anti-phospho-p44/42ERK and anti-p44/42 ERK antibodies were from Cell Signaling Technology (Danvers, MA). Rabbit anti-actin antibody was from Santa Cruz Biotechnology (Santa Cruz, CA). Horseradish peroxidase-conjugated anti-rabbit antibody, Dowex 1-X8 (formate form) resin with 200-400 mesh and Bradford assay were purchased from Bio-Rad (Mississauga, $\mathrm{ON}$ ). Anti-mouse IgG secondary antibody and ECL Western blotting detection reagents were from GE Healthcare (Oakville, ON). myo- $\left[{ }^{3} \mathrm{H}\right]$ Inositol was acquired from PerkinElmer Life Sciences (Waltham, MA). The QuantiTect SYBR green single-step RT-PCR was from Qiagen (Toronto, ON). Alexa-488 anti-mouse was purchased from Molecular Probes (Burlington, ON). GenElute Mammalian Total RNA miniprep kit, Hoechst 33342, (3(4,5-Dimethylthiazol-2-yl)-2,5-diphenyltetrazolium bromide (MTT), Xestospongin $\mathrm{C}$, and all other biochemical reagents were purchased from Sigma-Aldrich (St. Louis, MO). The Tat-peptides corresponding to the mGluR5 binding motif for Homer proteins (Homer peptide: YGRK KRRQRRRALTPPSPFRDS and Scramble peptide: YGR KKRRQRRRTRSLPSDPPAF [19] were purchased from CanPeptide (Pointe Claire, PQ).

\section{Animals}

CD1 and BL6/129-Grm5tm1Rod/J [47] mice were purchased from Charles River Labs and Jackson Laboratory, respectively. Mice were housed in an animal care facility at $23^{\circ} \mathrm{C}$ on a $12 \mathrm{~h} \mathrm{light} / 12 \mathrm{~h}$ dark cycle with food and water provided ad libitum. Animal care was in accordance with the University of Western Ontario Animal Care Committee.

\section{Primary astrocyte cultures}

Cortices were dissected from CD1 or BL6/129Grm5 individual littermate embryos (E15-16) and separated from the striatum, as previously described [20]. After dissociation in D-MEM/glucose/10\%FBS/Gentamycin/L-glutamine media, the cells were plated onto poly-D-lysine coated culture flasks and maintained at $37^{\circ} \mathrm{C}$ and $5 \%$ $\mathrm{CO}_{2}$. Plating media was replaced by fresh media the following day and every 4 days thereafter. At DIV 7, the primary cultures were shaken overnight at $260 \mathrm{rpm}$ at $37^{\circ} \mathrm{C}$ and washed three times with PBS to remove microglia. Cells were allowed to recover in fresh media and after 24 hours cells were trypsinized and re-plated onto poly-D-lysine coated plates at a density of 12,000 cells $/ \mathrm{cm}^{2}$. Experiments were performed at DIV 14-19. The purity of the astrocyte cultures was assessed by immunocytochemistry with mouse anti-GFAP (1:400) and Alexa-488 anti-mouse (1:500) by microscopy (with nuclear staining with Hoechst 33258) as adapted from [48].

\section{Oxygen/glucose deprivation experiments}

After one wash with glucose/ L-glutamine-free D-MEM, astrocyte cultures were incubated for different periods of time with the same media in a hypoxic chamber (COY Laboratory Products Inc.) at $37^{\circ} \mathrm{C}, 5 \% \mathrm{CO}_{2}$ and $0 \% \mathrm{O}_{2}$, as described previously [40]. Control cell plates $(0 \mathrm{~h})$ were maintained in normoxic conditions. After OGD, equal volume of DMEM/2X glucose/10\%FBS/Gentamycin/L-glutamine media was added to the cells. The media of control astrocyte cultures was replaced by equal volumes of D-MEM with $2 \mathrm{X}$ glucose and without glucose. The cells were incubated at $37^{\circ} \mathrm{C}, 5 \% \mathrm{CO}_{2}$ for $24 \mathrm{~h}$ (reperfusion).

\section{Western blotting}

Cells were harvested either immediately after the incubation in the hypoxic chamber (OGD), or after the $24 \mathrm{~h}$ reperfusion period with RIPA buffer $(10 \mathrm{mM}$ Tris- $\mathrm{HCl}$ $\mathrm{pH}=7.5,140 \mathrm{mM} \mathrm{NaCl}, 1 \%$ Nonidet P-40, 1\% sodium deoxycholate, $0.1 \%$ SDS). After solublization, insoluble material was removed by centrifugation and supernatant was used to determine protein concentration by Bradford assay. After dilution in SDS sample buffer, 75$100 \mu \mathrm{g}$ of protein was loaded into a $10 \%$ acrylamide SDS-PAGE gel. After electrophoresis, proteins were transferred to a nitrocellulose membrane. After blocking non-specific binding with $10 \%$ non-fat milk in TBS with 0.05\% Tween-20 (TBS-T), membranes were incubated with rabbit anti-mGluR5 (1:4000), rabbit anti-actin (1:10000), rabbit anti-phospho-pERK44/42 (1:1000), or rabbit anti-pERK44/42 (1:1000, after anti-phosphoERK stripping) antibodies overnight at $4^{\circ} \mathrm{C}$. After three washes with TBS-T, blots were incubated 1 hour at room temperature with HRP-conjugated anti-rabbit (1:10000) or anti-mouse (1:5000) antibodies [20]. After three washes with TBS-T, blots were developed with ECL and exposed to films.

\section{Quantitative real time reverse-transcript polymerase chain reaction (qRT-PCR)}

RNA samples were isolated with the GenElute Mammalian Total RNA miniprep kit and treated with DNAse I following the manufacturer instructions. $30 \mathrm{ng}$ of total 
RNA was used per reaction and mouse mGluR5 mRNA and the mitochondrial ribosomal protein S12 (endogenous housekeeping gene) mRNAs were amplified separately using the following primers: $5^{\prime}$ mGluR5: 5'GGTGGTAGCCTGCTTCTGTGA3' (exon2), 3'mGluR5: 5'CGCTGATACCCATCTGTCACG3' (exon3), 5'S12:, 5'GGAAGGCATAGCTGCTGG3', 3'S12: 5'CCTCGATGA CATCCTTGG3' using the QuantiTect SYBR green singlestep RT-PCR kit as per manufacturers' instructions. The comparative $\mathrm{Ct}$ method (2-[delta][delta]Ct) was used for quantification [49].

\section{Inositol phosphate formation assay}

Inositol lipids were radiolabeled by incubating the cortical astrocyte cultures overnight with $1 \mu \mathrm{Ci} / \mathrm{ml}$ myo$\left[{ }^{3} \mathrm{H}\right]$ inositol in D-MEM, as previously described by Ribeiro et al. [20]. In brief, incorporated myo- $\left[{ }^{3} \mathrm{H}\right]$ inositol was removed by washing cells with Hank's balanced salt solution (HBSS). Cells were transferred in D-MEM without glucose and placed in the hypoxic chamber or not (0 h OGD control) for $4 \mathrm{~h}$. After ischemia, $\mathrm{LiCl}$ was added to the wells to achieve a final concentration of $10 \mathrm{mM}$ and the cells were incubated for $30 \mathrm{~min}$ in presence or in absence of $10 \mu \mathrm{M}$ MPEP. The reactions were stopped on ice by the addition of $500 \mu \mathrm{l}$ of perchloric acid and then neutralized with $400 \mu \mathrm{l}$ of $0.72 \mathrm{M} \mathrm{KOH}$, 0.6 M KHCO3. Total $\left[{ }^{3} \mathrm{H}\right]$ inositol incorporated into cells was determined by counting the radioactivity present in $50 \mu \mathrm{l}$ of cell lysate. Total inositol phosphate was purified from cell extracts by anion exchange chromatography using Dowex 1-X8 (formate form) 200-400 mesh anion exchange resin. $\left[{ }^{3} \mathrm{H}\right]$ Inositol phosphate formation was determined by liquid scintillation.

\section{MTT cell viability assay}

After reperfusion, $1 / 10$ of media volume of $5 \mathrm{mg} / \mathrm{ml}$ MTT was added to the culture dishes and incubated at $37^{\circ} \mathrm{C}, 5 \% \mathrm{CO}_{2}$ for $3 \mathrm{~h}$. The reaction was then stopped by adding an equal volume of isopropanol. After trituration, the crystal deposits (converted dye) were dissolved by shaking for $20 \mathrm{~min}$. Absorbances at $570 \mathrm{~nm}$ and $690 \mathrm{~nm}$ (background) were read in triplicate and absorbance values were corrected for the absorbance due to the culture media in absence of cells [50].

\section{Hoechst staining}

As described by Steckley et al., [49] Hoechst 33342 dye was added in triplicate directly to live cells and incubated for $30 \mathrm{~min}$ at $37^{\circ} \mathrm{C}$. The media was then removed and the cells fixed in $3.7 \%$ formaldehyde for $60 \mathrm{~min}$ at RT. After three PBS washes, the cells were kept at $4{ }^{\circ} \mathrm{C}$ until imaged and apoptotic cells (condensed nuclei) were quantified using ImageJ software. For each experimental data point, 1000-2000 cells were counted from triplicate wells of sister cultures from at least 3 independent experiments.

\section{LDH release assay}

After OGD/reperfusion experiments, lysis buffer (10 mM Tris- $\mathrm{HCl} \mathrm{pH}=7.5,140 \mathrm{mM} \mathrm{NaCl}, 1 \%$ Nonidet P-40, $1 \%$ sodium deoxycholate, $0.1 \%$ SDS) was added to culture wells to determine the maximum $\mathrm{LDH}$ release. After $15 \mathrm{~min}$ incubation at $37^{\circ} \mathrm{C}$ and $5 \% \mathrm{CO}_{2}, 50 \mu \mathrm{l}$ aliquots of triplicate samples or cell-free culture media (background) were transferred to wells of a 96 well plate containing $50 \mu \mathrm{l}$ of PBS/well and experiments were performed according to the manufacturer instructions (Cytotoxicity detection kit plus, Roche). LDH release was determined by absorbance $\left(\mathrm{A}_{4.92} \mathrm{~nm}-\mathrm{A}_{690 \mathrm{~nm}}\right)$ measured using a SPECTRAmax M5 plate reader and expressed as percentage of the maximum release.

\section{Data analysis}

GraphPad Prism software was used to analyze data for statistical significance and for curve fitting. Statistical significance was determined by analysis of variance (ANOVA) testing followed by post-hoc Multiple Comparison testing.

\section{Abbreviations}

ERK: Extracellular regulated kinase; LDH: Lactose dehydrogenase; InsP: Inositol phosphate; mGluR: Metabotropic glutamate receptor; MPEP: 2-Methyl-6(phenylethynyl) pyridine hydrochloride; MTT: (3-(4,5-Dimethylthiazol-2-yl)-2,5diphenyltetrazolium bromide; OGD: Oxygen glucose deprivation;

PLC: Phospholipase C.

\section{Competing interests}

The authors declare that they have no competing interests.

\section{Authors' contributions}

$M P, F M R$, JG, and JLE performed the experiments included in the manuscript. LBD and TC provided technical assistance with cell cultures and confocal microscopy. SPC and SSGF conceived of the experiments and wrote the manuscript. All of the authors have read the manuscript.

\section{Acknowledgments}

MP was the recipient of a Canadian Institutes of Health Research (CIHR) postdoctoral fellowship award. FMR is the recipient of a Heart and Stroke Foundation of Canada Postdoctoral Fellowship. SPC and SSGF hold Canada Research Chairs and SSGF is a Career Investigator of the Heart and Stroke Foundation of Ontario. This work was supported by CIHR Grants MOP 119437 and MOP 111093 (SSGF) and CIHR Grant MOP 68995 and HSFO grant in aid NA 7380 (SPC)

\section{Author details}

1J. Allyn Taylor Centre for Cell Biology, Robarts Research Institute, Department of Physiology and Pharmacology, The University of Western Ontario, 100 Perth Drive, London, ON N6A 5K8, Canada. ${ }^{2}$ Departamento de Bioquimica e Imunologia, ICB, Universidade Federal de Minas Gerais, Belo Horizonte, Brazil.

Received: 8 February 2013 Accepted: 11 February 2013

Published: 14 February 2013

\section{References}

1. Conn PJ, Pin JP: Pharmacology and functions of metabotropic glutamate receptors. Annu Rev Pharmacol Toxicol 1997, 37:205-237. 
2. Ferguson SSG: Phosphorylation-independent attenuation of GPCR signaling. Trends Pharmacol Sci 2007, 28:173-179.

3. Ribeiro FM, Paquet M, Cregan SP, Ferguson SSG: Group I metabotropic glutamate receptor signaling and its implication in Neurological disease processes. CNS Neurol Disord Drug Targets 2010, 9:574-595.

4. Dhami GK, Ferguson SSG: Metabotropic glutamate receptor desensitization. Pharmacol Ther 2006, 111:260-271.

5. Biber K, Laurie DJ, Berthele A, Sommer B, Tolle TR, Gebicke-Harter PJ, van Calker D, Boddeke HW: Expression and signaling of group I metabotropic glutamate receptors in astrocytes and microglia. J Neurochem 1999, 72:1671-1680

6. Cai Z, Schools GP, Kimelberg HK: Metabotropic glutamate receptors in acutely isolated hippocampal astrocytes: developmental changes of mGluR5 mRNA and functional expression. Glia 2000, 29:70-80

7. Silva GA, Theriault E, Mills LR, Pennefather PS, Feeney CJ: Group I and II metabotropic glutamate receptor expression in cultured rat spinal cord astrocytes. Neurosci Lett 1999, 263:117-120.

8. D'Ascenzo M, Fellin T, Terunuma M, Revilla-Sanchez R, Meaney DF, Auberson YP, Moss SJ, Haydon PG: mGluR5 stimulates gliotransmission in the nucleus accumbens. Proc Natl Acad Sci U S A 2007, 104:1995-2000.

9. Vermeiren C, Hemptinne I, Vanhoutte N, Tilleux S, Maloteaux JM, Hermans E: Loss of metabotropic glutamate receptor-mediated regulation of glutamate transport in chemically activated astrocytes in a rat model of amyotrophic lateral sclerosis. J Neurochem 2006, 96:7197-7131.

10. Shi Y, Liu X, Gebremedhin D, Falck JR, Harder DR, Koehler RC: Interaction of mechanisms involving epoxyeicosatrienoic acids, adenosine receptors, and metabotropic glutamate receptors in neurovascular coupling in rat whisker barrel cortex. J Cereb Blood Flow Metab 2008, 28:111-125.

11. Nicoletti F, Bruno V, Catania MV, Battaglia G, Copani A, Barbagallo G, Cena V, Sanchez-Prieto J, Spano PF, Pizzi M: Group-I metabotropic glutamate receptors: hypotheses to explain their dual role in neurotoxicity and neuroprotection. Neuropharmacology 1999, 38:1477-1484.

12. Allen JW, Vicini S, Faden Al: Exacerbation of neuronal cell death by activation of group I metabotropic glutamate receptors: role of NMDA receptors and arachidonic acid release. Exp Neurol 2001, 169:449-460.

13. Bruno V, Battaglia G, Copani A, Cespedes VM, Galindo MF, Cena V, SanchezPrieto J, Gasparini F, Kuhn R, Flor PJ, Nicoletti F: An activity-dependent switch from facilitation to inhibition in the control of excitotoxicity by group I metabotropic glutamate receptors. Eur J Neurosci 2001, 13:1469-1478.

14. Baskys A, Bayazitov I, Fang L, Blaabjerg M, Poulsen FR, Zimmer J: Group I metabotropic glutamate receptors reduce excitotoxic injury and may facilitate neurogenesis. Neuropharmacology 2005, 49:146-156.

15. Pellegrini-Giampietro DE: The distinct role of $\mathrm{mGlu1}$ receptors in postischemic neuronal death. Trends Pharmacol Sci 2003, 24:461-470.

16. Rong R, Ahn JY, Huang H, Nagata E, Kalman D, Kapp JA, Tu J, Worley PF, Snyder SH, Ye K: PI3 kinase enhancer-Homer complex couples mGluRI to PI3 kinase, preventing neuronal apoptosis. Nat Neurosci 2003, 6:1153-1161.

17. Szydlowska K, Kaminska B, Baude A, Parsons CG, Danysz W: Neuroprotective activity of selective mGlu1 and mGlu5 antagonists in vitro and in vivo. Eur J Pharmacol 2007, 554:18-29.

18. Hilton GD, Nunez JL, Bambrick L, Thompson SM, McCarthy MM: Glutamatemediated excitotoxicity in neonatal hippocampal neurons is mediated by mGluR-induced release of $\mathrm{Ca}++$ from intracellular stores and is prevented by estradiol. Eur J Neurosci 2006, 24:3008-3016.

19. Mao L, Yang L, Tang Q, Samdani S, Zhang G, Wang JQ: The scaffold protein Homer $1 \mathrm{~b} / \mathrm{c}$ links metabotropic glutamate receptor 5 to extracellular signal-regulated protein kinase cascades in neurons. J Neurosci 2005, 25:2741-2752.

20. Ribeiro FM, Paquet M, Ferreira LT, Cregan T, Swan P, Cregan SP, Ferguson SS: Metabotropic glutamate receptor-mediated cell signaling pathways are altered in a mouse model of Huntington's disease. J Neurosci 2010, 30:316-324

21. Tu JC, Xiao B, Yuan JP, Lanahan AA, Leoffert K, Li M, Linden DJ, Worley PF: Homer binds a novel proline-rich motif and links group 1 metabotropic glutamate receptors with IP3 receptors. Neuron 1998, 21:717-726.

22. Aronica E, Gorter JA, Jansen GH, van Veelen CW, van Rijen PC, Ramkema M, Troost D: Expression and cell distribution of group I and group II metabotropic glutamate receptor subtypes in taylor-type focal cortical dysplasia. Epilepsia 2003, 44:785-795.

23. Ferraguti F, Corti C, Valerio E, Mion S, Xuereb J: Activated astrocytes in areas of kainate-induced neuronal injury upregulate the expression of the metabotropic glutamate receptors 2/3 and 5. Exp Brain Res 2001, 137:1-11.
24. Anneser JM, Chahli C, Ince PG, Borasio GD, Shaw PJ: Glial proliferation and metabotropic glutamate receptor expression in amyotrophic lateral sclerosis. J Neuropathol Exp Neurol 2004, 63:831-840.

25. Newcombe J, Uddin A, Dove R, Patel B, Turski L, Nishizawa Y, Smith T: Glutamate receptor expression in multiple sclerosis lesions. Brain Pathol 2008, 18:52-61.

26. Gelot A, Villapol S, Billette de Villemeur T, Renolleau S, Charriaut-Marlangue C: Astrocytic demise in the developing rat and human brain after hypoxic-ischemic damage. Dev Neurosci 2009, 31:459-470.

27. Jiang Z, Zhang Y, Chen XQ, Lam PY, Yang H, Xu Q, Yu AC: Apoptosis and activation of Erkl/2 and Akt in astrocytes postischemia. Neurochem Res 2003, 28:831-837.

28. Takuma K, Baba A, Matsuda T: Astrocyte apoptosis: implications for neuroprotection. Prog Neurobiol 2004, 72:1111-1127.

29. Yu AC, Wong HK, Yung HW, Lau LT: Ischemia-induced apoptosis in primary cultures of astrocytes. Glia 2001, 35:121-130.

30. Gurer G, Gursoy-Ozdemir Y, Erdemli E, Can A, Dalkara T: Astrocytes are more resistant to focal cerebral ischemia than neurons and die by a delayed necrosis. Brain Pathol 2009, 19:630-641.

31. Dolan S, Kelly JG, Monteiro AM, Nolan AM: Up-regulation of metabotropic glutamate receptor subtypes 3 and 5 in spinal cord in a clinical model of persistent inflammation and hyperalgesia. Pain 2003, 106:501-512.

32. Geurts JJ, Wolswijk G, Bo L, van der Valk P, Polman CH, Troost D, Aronica E: Altered expression patterns of group I and II metabotropic glutamate receptors in multiple sclerosis. Brain 2003, 126:1755-1766.

33. Ulas J, Satou T, Ivins K, Kesslak JP, Cotman CW, Balazs R: Expression of metabotropic glutamate receptor 5 is increased in astrocytes after kainate-induced epileptic seizures. Glia 2000, 30:352-361.

34. Prezeau L, Gomeza J, Ahern S, Mary S, Galvez T, Bockaert J, Pin JP: Changes in the carboxyl-terminal domain of metabotropic glutamate receptor 1 by alternative splicing generate receptors with differing agonistindependent activity. Mol Pharmacol 1996, 49:422-429.

35. Rossi DJ, Brady JD, Mohr C: Astrocyte metabolism and signaling during brain ischemia. Nat Neurosci 2007, 10:1377-1386.

36. Segeleon JE, Lipscomb DC, Haun SE, Trapp VL, Horrocks LA: Astroglial phosphoinositide hydrolysis during combined glucose-oxygen deprivation: role of the metabotropic glutamate receptor. J Neurochem 1995, 65:1115-1123.

37. Peavy RD, Chang MS, Sanders-Bush E, Conn PJ: Metabotropic glutamate receptor 5 -induced phosphorylation of extracellular signal-regulated kinase in astrocytes depends on transactivation of the epidermal growth factor receptor. J Neurosci 2001, 21:9619-9628.

38. Nicodemo AA, Pampillo M, Ferreira LT, Dale LB, Cregan T, Ribeiro FM, Ferguson SS: Pyk2 uncouples metabotropic glutamate receptor $\mathrm{G}$ protein signaling but facilitates ERK1/2 activation. Mol Brain 2010, 3:4.

39. Jiang Z, Zhang Y, Chen X, Lam PY, Yang H, Xu Q, Yu AC: Activation of Erk1/ 2 and Akt in astrocytes under ischemia. Biochem Biophys Res Commun 2002, 294:726-733.

40. Ciccarelli R, D'Alimonte I, Ballerini P, D'Auro M, Nargi E, Buccella S, Di lorio P, Bruno V, Nicoletti F, Caciagli F: Molecular signalling mediating the protective effect of A1 adenosine and mGlu3 metabotropic glutamate receptor activation against apoptosis by oxygen/glucose deprivation in cultured astrocytes. Mol Pharmacol 2007, 71:1369-1380.

41. Bruno V, Ksiazek I, Battaglia G, Lukic S, Leonhardt T, Sauer D, Gasparini F, Kuhn R, Nicoletti F, Flor PJ: Selective blockade of metabotropic glutamate receptor subtype 5 is neuroprotective. Neuropharmacology 2000, 39:2223-2230.

42. Rossi D, Brambilla L, Valori CF, Roncoroni C, Crugnola A, Yokota T, Bredesen $D E$, Volterra A: Focal degeneration of astrocytes in amyotrophic lateral sclerosis. Cell Death Differ 2008, 15:1691-1700.

43. Hanson CJ, Bootman MD, Roderick HL: Cell signalling: IP3 receptors channel calcium into cell death. Curr Biol 2004, 14:R933-R935.

44. Cancer Genome Atlas Research Network: Integrated genomic analyses of ovarian carcinoma. Nature 2011, 474:609-615.

45. Cancer Genome Atlas Research Network: Comprehensive genomic characterization defines human glioblastoma genes and core pathways. Nature 2008, 455:1061-1068.

46. Esseltine JL, Willard ML, Wulur IH, Lajiness ME, Barber TD, Ferguson SSG: Somatic mutations in GRM1 in cancer alter metabotropic glutamate receptor 1 intracellular localization and signaling. Mo Pharmacol 2013, [Epub ahead of print]. 
47. Lu YM, Jia Z, Janus C, Henderson JT, Gerlai R, Wojtowicz JM, Roder JC: Mice lacking metabotropic glutamate receptor 5 show impaired learning and reduced CA1 long-term potentiation (LTP) but normal CA3 LTP. J Neurosci 1997, 17:5196-5205.

48. McCarthy KD, de Vellis J: Preparation of separate astroglial and oligodendroglial cell cultures from rat cerebral tissue. J Cell Biol 1980, 85:890-902.

49. Steckley D, Karajgikar M, Dale LB, Swan P, Fuerth B, Drummond-Main C, Poulter MO, Ferguson SSG, Strasser A, Cregan SP: Puma is a dominant regulator of oxidative stress induced bax activation and neuronal apoptosis. J Neurosci 2007, 27:12989-12999.

50. Cregan SP, Arbour NA, Maclaurin JG, Callaghan SM, Fortin A, Cheung EC, Guberman DS, Park DS, Slack RS: p53 activation domain 1 is essential for PUMA upregulation and p53-mediated neuronal cell death. J Neurosci 2004, 24:10003-10012.

doi:10.1186/1756-6606-6-9

Cite this article as: Paquet et al:: Role of metabotropic glutamate receptor 5 signaling and homer in oxygen glucose deprivationmediated astrocyte apoptosis. Molecular Brain 2013 6:9.

\section{Submit your next manuscript to BioMed Central and take full advantage of:}

- Convenient online submission

- Thorough peer review

- No space constraints or color figure charges

- Immediate publication on acceptance

- Inclusion in PubMed, CAS, Scopus and Google Scholar

- Research which is freely available for redistribution 